Open Access

Res. Agric. Livest. Fish.

Research Article

Vol. 2, No. 1, April 2015: 151-160

\title{
ABUNDANCE AND COMPOSITION OF ZOOPLANKTON AT SITAKUNDA COAST OF CHITTAGONG, BANGLADESH
}

\author{
Md. Shahzad Kuli Khan ${ }^{1^{*}}$, Sheikh Aftab Uddin² and Mohammed Ashraful Haque ${ }^{1}$ \\ ${ }^{1}$ Bangladesh Fisheries Research Institute, Marine Fisheries and Technology Station, \\ Cox's Bazar-4700, Bangladesh \\ ${ }^{2}$ Institute of Marine Sciences and Fisheries, University of Chittagong, Chittagong-4331, \\ Bangladesh
}

*Corresponding author: Md. Shahzad Kuli Khan, E-mail: khanbfri@gmail.com

\section{ARTICLE INFO ABSTRACT}

Received

19.03.2015

Accepted

12.04.2015

Online

19.04.2015

Key words

Mangrove area

Zooplankton

Copepoda

Fish larvae

\begin{abstract}
Eight groups of zooplankton were found at Sitakunda coast, Chittagong, northeastern part of the Bay of Bengal during January to June 2007. The identified groups were Appendicularia $(2.46 \%)$, Chaetognatha $(2.45 \%)$, Cladocera $(2.31 \%)$, Copepoda (26.05\%), Ctenophora (5.86\%), Crustacean zooplankton (21.64\%), Ichthyoplankton $(17.77 \%)$ and Meroplankton (21.45\%). Abundance of zooplankton varied from 413 to 7730 individuals $/ \mathrm{m}^{3}$.Mangrove vegetate area (station- $\mathrm{VI}$ ) has the highest abundant possibly due to the organic and inorganic matters dissolved in the water while ship breaking area (station- IV) has the lowest abundant. Zooplankton population was significantly $(p>0.05)$ higher in the mangrove vegetate area than the fishermen community area and ship breaking area. The mangrove vegetate area has the highest composition (57.06\%) of zooplankton than the fishers community area and ship breaking area $(29.77 \%$ and $13.16 \%$, respectively). Calanus sp. $(12.29 \%)$ belonging to Copepods and fish eggs $(9.25 \%)$ belonging to Ichthyoplankton were the most abundant and Oikopleura albicans (0.66\%) from Appendicularia, Metapenaeus brevicornis $(0.71 \%)$ and Metapenaeus monoceros $(0.90 \%)$ belonging to Crustacean larvae were the lowest abundant species found at three major investigated area.
\end{abstract}

To cite this article: MSK Khan, SA Uddin and MA Haque. 2015. Abundance and composition of zooplankton at sitakunda coast in Chittagong, Bangladesh. Res. Agric. Livest. Fish. 2 (1): 151-160.

This is an open access article licensed under the terms of 


\section{INTRODUCTION}

Zooplankton is an aquatic animal community that has limited swimming capacity against the ambient currents. Even with their quite limited swimming capacity, they carry out day-night periodic movements of hundreds of meters. They prefer to feed at night on the water surface and effectively graze the phytoplankton, and hence they referred to as living machines. They habitually represent a vital link between the microbial portion and the large grazers (Laval-Peuto et al., 1986; Pierce and Turner, 1994). The zooplankton, secondary consumer plays a key role in the food chain of aquatic ecosystem by transferring energy from phytoplankton to higher tropic levels leading to the production of fisheries to human exploitation. The health of marine ecosystems inherently linked to the abundance of zooplankton and their biodiversity. The potentiality of marine pelagic fishes directly or indirectly depends on the availability of zooplankton. In the aquatic ecosystem zooplankton are being used as the indicator species for the physical, chemical and biological processes due to their universal distribution, small size, and rapid metabolic and growth rates (Heinbokel, 1978; Fenchel, 1987), huge density, tinier life span, drifting nature, great species diversity and diverse tolerance to the stress (Gajbhiye, 2002).

A survey report of FAO (1985) stated that the tidal areas of Bangladesh are relatively rich in zooplankton. The abundance of zooplankton and their ecology in the coastal and estuarine environment of Bangladesh is little studied. Islam and Aziz (1975) studied on zooplankton of the northeastern part of the Bangladesh coastal area and identified a total of 18 genera and 18 species. Bhuyain et al. (1982) made an observation on the macro-zooplankter of the continental shelf of the Bay of Bengal and reported the occurrence and distribution of 18 calanoid copepods. Ali et al. (1985) recorded a periodic variation of zooplankton in the coastal estuarine water in the southeastern part of Bangladesh. The major groups of zooplankton are copepoda, decapoda, chaetognatha, cladocera and fish and shellfish larvae. Zooplankton diversity of salt marsh habitat in the Bakkhali river estuary, Cox's Bazar, Bangladesh has also studied by Ali (2006).

Coastal zone contains critical terrestrial and aquatic habitats, such as mangrove forests, wetlands and tidal flats. Sitakunda coast under the Chittagong district, northeastern part of the Bay of Bengal is adjacent to the Sandwip Chanel, having tidal mangrove, ship breaking yard and fishermen community area and an important source of fisheries resources. The purpose of this study is to provide more information on the abundance and composition of the zooplankton community on the Sitakunda Upazila coastal water, north of the Chittagong city, which is currently affected by ship-breaking activity on the shore.

\section{MATERIALS AND METHODS}

Sitakunda coast, which is the northeastern part of the Bay of Bengal, located in between $22^{\circ} 22^{\prime}$ and $22^{\circ} 42^{\prime}$ northern latitudes and in between $91^{\circ} 34^{\prime}$ and $91^{\circ} 48^{\prime}$ east longitudes. For the present investigation this coastal area was divided into three pre define activities community with six sampling stations (Fig. 1).Station-I (Salimpur) and station-II (Saidpur) was considered as a fishermen community area, station-III (Grisubedar Ship yard) and station-IV (PHP Ship yard) located in Bhatiari area was considered as ship breaking yard and station-V (Barabkunda) and station-VI (Muradpur) was considered as a tidal mangrove vegetate area.

\section{Zooplankton sampling and isolation}

The sampling was conducted during January to June 2007 by using a wooden boat. Zooplanktons were collected using a net (Hydrobios model $55 \mu \mathrm{m}$ mesh size) ending with a cod end to retain the organisms which was towed horizontally. A flow meter (FMC 0.3) was attached within the aperture of the net to measure the amount of water displaced. At each station, the net was slanted three times for 45 minutes each while the boat was moving slowly. The sampling was taken place in the sub-surface layer $(0.2 \mathrm{~m}-0.5 \mathrm{~m})$ of the water column. Abundance of organisms was calculated from the volume of water displaced through the plankton net and expressed as numbers of individuals per cubic meter. Immediately after collection, the samples were preserved in $4 \%$ formalin ( $45 \%$ formaldehyde) in $250 \mathrm{ml}$ plastic bottles and labeled. Then the samples brought to the laboratory of Institute of Marine Sciences and Fisheries, University of Chittagong for qualitative and quantitative analysis. For efficient sorting, a vital stain "Rose Bengal" was added and the sample left for overnight. Zooplanktons were sorted out with the help of fine brushes, needle, forceps and an inverted microscope (Model-Axiovert 25, CFL) and Sedgwick-Rafter chamber was used for counting. 
Major groups were identified by the works of Patel (1975), Kasturirangan (1963), Koga (1984), Zafar and Mahmud (1989) for Copepoda; Wickstead (1965) and Smirnov (1996) for Cladocera; Srinivasan (1988), Andreu et al.(1989) and Bieri (1991) for Chaetognatha; Haq and Hasan (1975), Muthu et al. (1978), Amin and Mahmud (1979), Paulinose (1982), Deshmukh and Kagwade (1987), Rothlisberg (1983, 1987), Tirmizi et al. (1987) and Zafar (2000) for Crustacean zooplankton; Peter (1969), Newell and Newell (1979), Omori and Ikeda (1984), Zafar and Mahmud (1989), Olivar and Fortuno (1991) and Goswami \& Padmavati (1996) for Meroplankton and Ichthyoplankton.

\section{Data analysis}

The zooplankton abundance was calculated using the following formula:

a. Total number of zooplankton specimens $=$ Total counts of the specimens (say $\mathrm{x}$ )/ Volume of water filtered (V).

No. $/ \mathrm{m} 3=x / v$ (No. can also be expressed $/ 100 \mathrm{~m}^{-3}$ or $1000 \mathrm{~m}^{-3}$ ).

b. Total number of specimens of a particular zooplankton taxon

$=$ Total counts $(\mathrm{x}) /$ Volume of water filtered $(\mathrm{Y})$

No. $/ \mathrm{m} 3=\mathrm{x} / \mathrm{y}$.

SAS (2003) was used to analyze the data for analysis of variance (ANOVA).

\section{RESULTS}

Eight groups of zooplankton were identified, i.e. Appendicularia, Chaetognatha, Cladocera, Copepoda, Ctenophora, Crustacean zooplankton, Ichthyoplankton and Meroplankton at six different stations on Sitakunda coast, Chittagong, Bangladesh. In total 10 known species of Crustacean, 7 known and unidentified species of Meroplankton, 6 species of Copepoda, each 2 species of Appendicularia, Ctenophora and Ichthyoplankton and each one species of Cladocera and Chaetognatha were identified during the investigation. Abundance of zooplankton varied from 413 to 7730 individuals $/ \mathrm{m}^{3}$. Figure 2 ( $\mathrm{A}$ and $\mathrm{B}$ ) shows the composition of the various zooplankton group on Sitakunda coast and the contribution of those groups in each station.

\section{Appendicularia}

This class includes Oikopleura albicans and $O$. dioica, comprising together $2.46 \%$ of the total zooplankton population. They live in the pelagic zone, especially in the upper sunlight portion of the ocean. These zooplanktons were found in all stations, but in low number $\left(63 \mathrm{indi} / \mathrm{m}^{3}\right)$ was observed in the Bhatiyari area near the ship breaking yard and large number $\left(1150 \mathrm{indi} / \mathrm{m}^{3}\right)$ were observed in the mangrove vegetate area. Among them, a few 0 . albicans $\left(12\right.$ indi $\left./ \mathrm{m}^{3}\right)$ was found in ship breaking area.

\section{Cladocera}

Cladocera the lowermost group made only $2.32 \%$ of the total zooplankton population and Evadue sp. was the only identified zooplankton, which was very common in all stations. The abundance of Evadue $s p$. was $56 \mathrm{indi} / \mathrm{m}^{3}$ to 503 indi $/ \mathrm{m}^{3}$.

\section{Ctenophora}

The ctenophores designed $5.86 \%$ of the total zooplankton population. This group composed of Bolinopsis vitrea and Pleurobrachia sp. and the percentage occurred $2.81 \%$ and $3.05 \%$ respectively.

\section{Chaetognatha}

Chaetognatha were the second lowermost group, forming $2.45 \%$ of total zooplankton. In mangrove vegetate and fishermen community area, they found great number compare to ship breaking area near Bhatiyari. The highest abundance was $507 \mathrm{indi} / \mathrm{m}^{3}$ and the lowest was $64 \mathrm{indi} / \mathrm{m}^{3}$. 


\section{Copepoda}

Copepods were the most abundant group encompassing $26.05 \%$ of the total zooplankton population. This group consisted with Calanus sp., Microsetella sp., Oncaea sp., Calanopia sp., Coryeacus sp. and Oithona sp. During the study highest abundance $1,937 \mathrm{indi} / \mathrm{m}^{3}$ was found in mangrove vegetate area (station VI) due to the high number of Calanus sp. while station-III \& IV (Ship breaking area) was the lowest abundance 2 indi $/ \mathrm{m}^{3}$ and 7 indi $/ \mathrm{m}^{3}$ respectively owing to Oncaea sp. Calanus sp. was the most abundant and found at all stations, comprising $12.29 \%$ of the total zooplankton population.

\section{Crustacean zooplankton}

Crustaceans were the second most plentiful group of zooplankton, founding $21.64 \%$ of the total population. This group was composed of Acetes larvae (7.87\%), Lucifer larvae (4.14\%), Penaeid larvae $(7.41 \%)$ and Sergestes larvae $(2.22 \%)$. The Acetes larvae were very common in this study. Assets erythraeus $(2.67 \%)$, Acetes indicus (2.69\%) and Acetes japonicas (2.51\%) accounted for the majority of the crustacean zooplankton. The highest number $\left(819 \mathrm{indi} / \mathrm{m}^{3}\right)$ of Acetes erythraeus occurred in the mangrove vegetate area (i.e. st. $\mathrm{VI})$ and the lowest number $\left(19 \mathrm{indi} / \mathrm{m}^{3}\right)$ in ship breaking area.

\section{Lucifer}

Lucifer sp. was very common and made only $4.14 \%$ of the total zooplankton population. The amount of Lucifer $s p$. was quite high in mangrove vegetate and fishermen community water while the number was lower in the ship breaking area. The average abundance showed substantial differences in those places.

\section{Shrimp larvae}

Penaeus and Metapenaeus larvae were regular component in the Penaeid zooplankton, constituting $5.81 \%$ and $1.61 \%$ of the total zooplankton population respectively. Among them $P$. indicus was most dominant species (1473 indi $/ \mathrm{m}^{3}$ ) occurred in mangrove vegetate area (station $\left.\mathrm{VI}\right)$. The abundance was very low at ship breaking area for all species, i.e. $P$. monodon $\left(19 \mathrm{indi} / \mathrm{m}^{3}\right), P$. indicus $\left(100 \mathrm{indi} / \mathrm{m}^{3}\right), P$. merguiensis $(14$ indi $\left./ \mathrm{m}^{3}\right)$, Metapenaeus monoceros $\left(12 \mathrm{indi} / \mathrm{m}^{3}\right)$ and Metapenaeus brevicornis $\left(15 \mathrm{indi} / \mathrm{m}^{3}\right)$.

In all stations, Sergestes similis also found in worthy number. In mangrove vegetation $\left(926 \mathrm{indi} / \mathrm{m}^{3}\right)$ and fishermen community area $\left(395 \mathrm{indi} / \mathrm{m}^{3}\right)$ the number was high, but in the ship breaking area $\left(74 \mathrm{indi} / \mathrm{m}^{3}\right)$ the number was very low.

\section{Meroplankton}

Meroplankton consisted of Polychaete larvae (5.28\%), Snail veliger (2.77\%), Snail larvae $(2.34 \%)$, Barnacle nauplius (2.18\%), Barnacle cyprid (2.36\%), Crab megalopa (3.12\%) and Crab zoea (3.41\%). Polychaete larvae were very common zooplankton and high in number. The average abundance in all stations showed no significant differences. Snail veligers and Snail larvae were also available at all stations. The amount of Barnacle nauplius and Barnacle cyprid was high in mangrove and fishermen community area rather than ship breaking area.

\section{Ichthyoplankton}

Fish eggs and larvae were very common and high in number, creating $9.25 \%$ and $8.52 \%$ of total zooplankton respectively. Fish eggs and larvae found available in all investigated areas. The average abundance showed no significant differences between mangroves vegetate area and ship breaking area.

\section{DISCUSSION}

A sensible variation was observed in the zooplankton abundance in all stations. Mangrove vegetate area have the highest abundant 35,755 individuals $/ \mathrm{m}^{3}$ and fishermen community area and ship breaking yard has 18,825 individuals $/ \mathrm{m}^{3}$ and 8,321 individuals $/ \mathrm{m} 3$, respectively around the sampling period. Statistical analysis showed that the abundance of zooplankton population in the mangrove vegetate area was significantly higher $(p>0.05)$ than the fishers community area and ship breaking area. The mangrove vegetate area has the highest composition (57.06\%) of zooplankton then the fishers community area and ship breaking area (29.77\% and $13.16 \%$, respectively). 


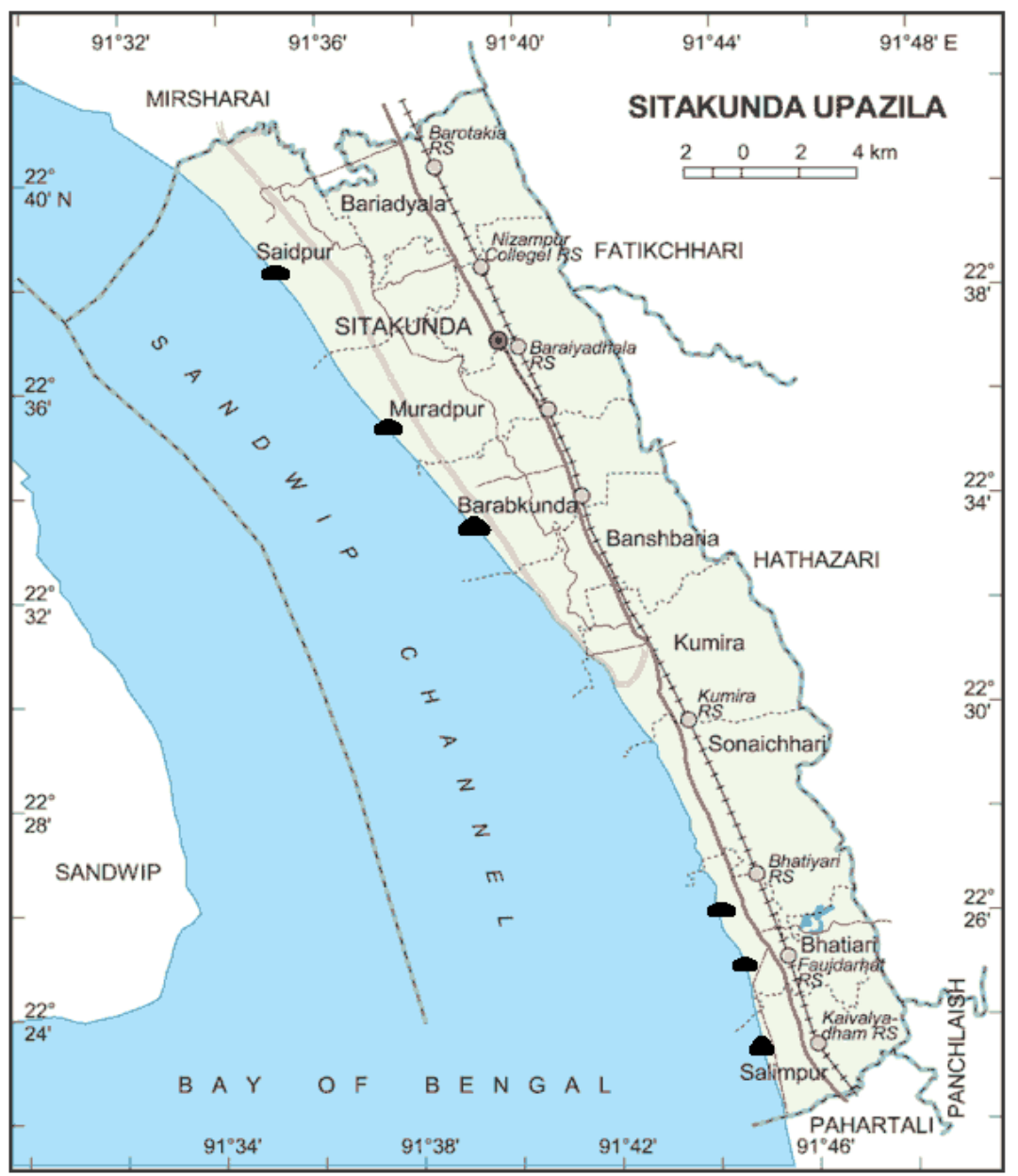

Figure 1. Map of study area (Sitakunda coast) with the location of sampling stations.

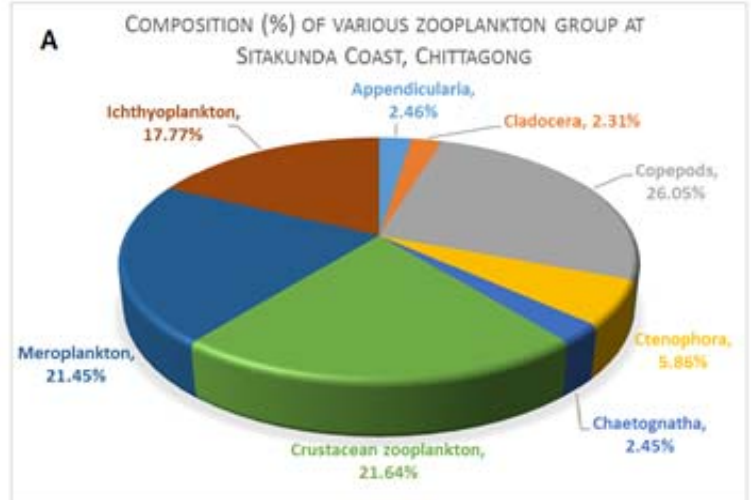

B Richness (\%) of various zooplankton groups at different
sampling station

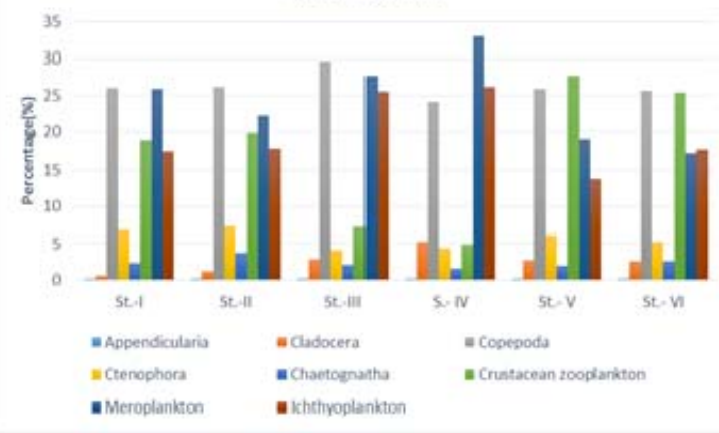

Figure 2. Percent composition of various zooplanktons $(A)$ and their richness at different sampling station (B). 
Table 1. List of major groups and species of zooplankton identified and their number and percentage at Sitakunda coast, Chittagong

\begin{tabular}{|c|c|c|c|c|}
\hline Group & Species & Total No. & $\begin{array}{l}\text { Percentage (\%) } \\
\text { within group }\end{array}$ & Overall (\%) \\
\hline \multirow{3}{*}{ Appendicularia } & Oikopleuradioica & 1135 & 73.32 & 1.80 \\
\hline & Oikopleuraalbicans & 413 & 26.68 & 0.66 \\
\hline & Calanus sp. & 7730 & 47.18 & 12.29 \\
\hline \multirow{4}{*}{ Copepods } & Microsetellasp. & 4993 & 30.48 & 7.94 \\
\hline & Oncaeasp. & 852 & 5.20 & 1.35 \\
\hline & Calanopiasp. & 639 & 3.90 & 1.01 \\
\hline & Coryeacussp. & 1312 & 8.01 & 2.08 \\
\hline \multirow{3}{*}{ Cladocera } & Oithonasp. & 857 & 5.23 & 1.36 \\
\hline & Evaduesp. & 1457 & 43.17 & 2.32 \\
\hline & Pleurobrachia sp. & 1918 & 56.83 & 3.05 \\
\hline Ctenophores & Bolinopsisvitrea & 1767 & 100 & 2.81 \\
\hline \multirow[t]{5}{*}{ Chaetognatha } & Sagittasp. & 1544 & 100 & 2.45 \\
\hline & Lucifer sp. & 2602 & 19.11 & 4.14 \\
\hline & Sergestessimilis & 1395 & 10.25 & 2.22 \\
\hline & Penaeus monodon & 1361 & 10.00 & 2.16 \\
\hline & Penaeus merguiensis & 818 & 6.00 & 1.30 \\
\hline \multirow{9}{*}{ Crustacean } & Metapenaeus monoceros & 566 & 4.16 & 0.90 \\
\hline & Metapenaeus brevicornis & 447 & 3.28 & 0.71 \\
\hline & Penaeus indicus & 1473 & 10.82 & 2.34 \\
\hline & Aceteserythraeus & 1694 & 12.44 & 2.67 \\
\hline & Acetesindicus & 1681 & 12.35 & 2.69 \\
\hline & Acetesjaponicus & 1577 & 11.58 & 2.51 \\
\hline & Polychaete larvae & 3320 & 24.61 & 5.28 \\
\hline & Snail veliger & 1740 & 12.90 & 2.77 \\
\hline & Snail larvae & 1472 & 10.90 & 2.34 \\
\hline \multirow[t]{4}{*}{ Meroplankton } & Barnacle nauplius & 1369 & 10.15 & 2.18 \\
\hline & Barnacle cyprid & 1483 & 10.99 & 2.36 \\
\hline & Crab megalopa & 1960 & 14.53 & 3.12 \\
\hline & Crab zoea & 2148 & 15.92 & 3.41 \\
\hline \multirow{2}{*}{ Ichthyoplankton } & Fish eggs & 5820 & 52.07 & 9.25 \\
\hline & Fish larvae & 5358 & 47.93 & 8.52 \\
\hline Total & & 62901 & & 100 \\
\hline
\end{tabular}


Table 2. Zooplankton abundance (individual $/ \mathrm{m}^{3}$ ) and their averages in fishers community area (St.-I and II), ship breaking area (St.-III and IV) and mangrove vegetate area (St.-V and VI) at Sitakunda coast, Chittagong.

\begin{tabular}{|c|c|c|c|c|c|c|c|c|c|}
\hline \multirow{2}{*}{ Species } & \multirow{2}{*}{ St-I } & \multirow{2}{*}{ St-II } & \multirow{2}{*}{ St- III } & \multirow{2}{*}{ St- IV } & \multirow{2}{*}{ St- V } & \multirow{2}{*}{ St- VI } & \multirow{2}{*}{ Average } & \multirow{2}{*}{ Total } & \multirow{2}{*}{$\begin{array}{l}\text { Overall } \\
\%\end{array}$} \\
\hline & & & & & & & & & \\
\hline Aceteserythraeus & 109 & 98 & 32 & 19 & 372 & 487 & 186.17 & 1117 & 1.78 \\
\hline Acetesindicus & 211 & 47 & 9 & 3 & 112 & 179 & 93.5 & 561 & 0.89 \\
\hline Acetesjaponicus & 149 & 1236 & 867 & 693 & 1884 & 1937 & 1127.67 & 6766 & 10.76 \\
\hline Barnacle nauplius & 357 & 913 & 118 & 107 & 1353 & 1749 & 766.17 & 4597 & 7.31 \\
\hline Barnacle cyprid & 297 & 112 & 2 & 7 & 286 & 366 & 178.33 & 1070 & 1.70 \\
\hline Bolinopsisvitrea & 218 & 49 & 98 & 24 & 177 & 189 & 125.83 & 755 & 1.20 \\
\hline Calanopiasp. & 102 & 118 & 79 & 81 & 298 & 419 & 182.83 & 1097 & 1.74 \\
\hline Calanus sp. & 1113 & 94 & 98 & 72 & 253 & 311 & 323.5 & 1941 & 3.09 \\
\hline Coryeacussp. & 317 & 119 & 118 & 214 & 447 & 503 & 286.33 & 1718 & 2.73 \\
\hline Crab megalopa & 277 & 399 & 66 & 91 & 533 & 427 & 298.83 & 1793 & 2.85 \\
\hline Crab zoea & 319 & 307 & 107 & 87 & 472 & 576 & 311.33 & 1868 & 2.97 \\
\hline Evaduesp. & 56 & 354 & 87 & 64 & 321 & 507 & 231.5 & 1389 & 2.21 \\
\hline Fish eggs & 719 & 565 & 27 & 49 & 703 & 754 & 469.5 & 2817 & 4.48 \\
\hline Fish larvae & 892 & 188 & 72 & 2 & 521 & 405 & 346.67 & 2080 & 3.31 \\
\hline Lucifer sp. & 504 & 201 & 12 & 7 & 425 & 532 & 280.17 & 1681 & 2.67 \\
\hline M. brevicornis & 37 & 127 & 2 & 12 & 254 & 327 & 126.5 & 759 & 1.21 \\
\hline M. monoceros & 56 & 83 & 7 & 5 & 211 & 204 & 94.333 & 566 & 0.90 \\
\hline Microsetellasp. & 753 & 49 & 12 & 3 & 142 & 204 & 193.83 & 1163 & 1.85 \\
\hline Oikopleuraalbicans & 63 & 201 & 58 & 42 & 477 & 518 & 226.5 & 1359 & 2.16 \\
\hline Oikopleuradioica & 127 & 147 & 23 & 19 & 577 & 819 & 285.33 & 1712 & 2.72 \\
\hline Oithonasp. & 29 & 181 & 54 & 34 & 689 & 512 & 249.83 & 1499 & 2.38 \\
\hline Oncaeasp. & 79 & 173 & 36 & 27 & 554 & 638 & 251.17 & 1507 & 2.40 \\
\hline Penaeus indicus & 177 & 649 & 451 & 521 & 553 & 589 & 490 & 2940 & 4.67 \\
\hline Penaeus merguiensis & 96 & 247 & 117 & 98 & 537 & 429 & 254 & 1524 & 2.42 \\
\hline Penaeus monodon & 184 & 171 & 68 & 59 & 414 & 501 & 232.83 & 1397 & 2.22 \\
\hline Pleurobrachia sp. & 402 & 209 & 17 & 21 & 346 & 419 & 235.67 & 1414 & 2.25 \\
\hline Polychaete larvae & 557 & 119 & 9 & 54 & 483 & 521 & 290.5 & 1743 & 2.77 \\
\hline Sagittasp. & 211 & 321 & 236 & 361 & 354 & 411 & 315.67 & 1894 & 3.00 \\
\hline Sergestessimilis & 207 & 431 & 276 & 234 & 427 & 461 & 339.33 & 2036 & 3.24 \\
\hline Snail larvae & 259 & 1031 & 612 & 503 & 1236 & 1719 & 893.33 & 5360 & 8.52 \\
\hline Snail veliger & 312 & 697 & 473 & 565 & 1019 & 1712 & 796.33 & 4778 & 7.60 \\
\hline Total kind & 31 & 31 & 31 & 31 & 31 & 31 & 31 & 31 & \\
\hline Total individual & 9189 & 9636 & 4243 & 4078 & 16430 & 19325 & 10483.5 & 62901 & $100 \%$ \\
\hline
\end{tabular}


Large carnivorous zooplankters namely, the Ctenophora and Chaetognatha are planktonic predators of fish larvae. The correlation between fish larvae and their predators, i.e. Chaetognatha, and Ctenophora was $0.8611,0.8083$ respectively, at $95 \%$ confidence. The correlation of fish larvae and Copepoda, which their prey species was 0.9100 at $95 \%$ confidence.

At all stations, the dominant species in the Sitakunda coast were as Calanus sp., Microsetella sp. belonging to Copepods, fish eggs and fish larvae belonging to Ichthyoplankton, Polychaete larvae and Crab zoea belonging to Meroplankton and Lucifer sp. belonging to Crustacean larvae. All most all species were lower at station III and IV, which was denoted as the ship breaking area probably due to oil pollution and other human activities. Copepods were the main contributors in the present investigation. Wimpenny (1966) and Omori and Ikeda (1976) reported that copepods are the most abundant zooplankton communities sampled in the world ocean. Houde and Lovdal (1982) showed that copepods are important components of larval fish food. The present investigation on Crustacean zooplankton found five commercially important species such as Penaeus monodon, Penaeus merguiensis, Metapenaeus monoceros, Metapenaeus brevicornis and Penaeus indicus. Penaeus and Metapenaeus have worldwide commercial importance in fisheries and aquaculture, and the larvae of many species have been reared in the respected shrimp hatchery.

In general, particularly in coastal waters, the composition and abundance of zooplankton varied remarkably due to the seasonal variations and their sheltered systems like coastal and mangrove waters. On the Sitakunda coast, in the mangrove vegetate area, total abundance of zooplankton was higher than the fishermen community area and ship breaking area. This is because of organic and inorganic matters dissolved in the water, which is ultimately support directly or indirectly to the zooplankton growth. Similar results have also been reported in the coastal waters of Bangladesh by Bhuiyan et al. (1982), Ali et al. (1985) and Zafar (2000).

Fraser (1969) and Suwanrunpha (1983) reported that big carnivorous zooplankters namely Ctenophora, Chaetognatha, Medusae and Siphonophora are planktonic predators of fish larvae. In this study, a high correlation between fish larvae and their predator, especially chaetognatha was observed. Thus, their presence in numbers of zooplankton could have a serious effect on the recruitment of larval fish and could be very significant for the fish stocks and for the fishing industry. Houde and Lovdal (1982), Balbontin et al. (1986) and Anderson (1994) presented that small zooplankton e.g. Copepods, Tintinnids, Cladocerans, larval molluscs etc. are important components of larval fish food. The present study found a high correlation between fish larvae and their prey, especially copepods. Positive correlations indicated that fish tend to aggregate where the standing stock of copepods is highest. However, Sameoto (1972) found no significant correlation between standing stock of copepods and the valued abundance of herring larvae. Manyauthors point out that zooplankton was influencing on fisheries. Krisshnapillai and Bhat (1981) found that the fishcatching rate was maximum in while the zooplankton productive rate was high. Jacob et al. (1981) reported that the peak times in the zooplankton biomass coincided with the peak periods of pelagic fisheries.

Unfortunately, information about the fisheries in the present studied areas was not available, so that correlation of fish catch and zooplankton abundance was not measured.

\section{CONCLUSION}

The zooplankton abundance in the three locations showed a much different from each other. The zooplankton abundance in mangrove vegetate area was higher than the fishermen community and ship breaking area. The abundance and composition of the zooplankton can be used as an indicator of marine productivity. 


\section{REFERENCE}

1. Ali A, S Sukanta and N Mahmood, 1985. Seasonal abundance of plankton in Moheskhali channel, Bay of Bengal. In: Proceedings of SAARC Seminar on Protection of Environmental from Degradation, Dhaka, Bangladesh, p 128-140.

2. Ali, M. 2006. Zooplankton diversity of salt marsh habitat in the Bakkhali river estuary, Cox'Bazar, Bangladesh.4th Year Project Paper, Institute of Marine Sciences and Fisheries (IMSF), University of Chittagong. 56 p.

3. Amin $\mathrm{MN}$ and $\mathrm{N}$ Mahmood, 1979. On identification of post larvae of penaeid shrimp Metapenaeus brevicornis (H. Milne Edwards), Bangladesh Journal of Scientific and Industrial Research,14: 97-100.

4. Anderson JT, 1994. Feeding ecology and condition of larval and pelagic juvenile redfish, Sebastesspp. Marine Ecology Progress Series, 104: 211-226.

5. Andreu P, C Marrase and E Berdalet, 1989. Distribution of epiplanktonicChaetognatha along a transect in the Indian Ocean. Journal of Plankton Research, 11 (2): 185-192.

6. Balbontin F, M Garreton and J Neuling, 1986. Stomach content and prey size of the fish larvae from Bransfield Strait (SIBEX-Phase 2, Chile). SerieCientifica. InstitutoAntarticoChileno, 35: 125-144.

7. Bhuiyan AL, SA Mohi, SA Khair and NG Das, 1982. Macro-zooplanktons of the continental shelf of the Bay of Bengal. Chittagong University Studies, 6: 51-59.

8. Bieri R, 1991. Systematics of the Chaetognatha. In: The biology of chaetognaths: Eds,. Bone, Q. H. Kapp and A.C. Pierrot-Builts. Oxford University Press.p 122-136.

9. Deshmukh VD and PV Kagwade, 1987. Larval abundance of non-penaeid prawns in the Bombay Harbor. Journal of Marine Biological Association India, 29(1\&2): 291-296.

10. FAO 1985. Reported on tidal area study Bangladesh.Fisheries Resources Survey System

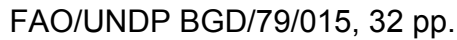

11. Fenchel T, 1987, Ecology of Protozoa - The Biology of Free Living PhagotrophicProtists SpringerVerlag, Berlin, p. 197.

12. Fraser JH, 1969. Experimental feeding of some Medusae and Chaetognatha. Journal of the Fisheries Research Board of Canada, 26: 1743-1762.

13. Gajbhiye SN, 2002. Zooplankton - Study methods, importance and significant observations.In: Quardros G, (Ed.) The National Seminar on Creeks, Estuaries and Mangroves - Pollution and Conservation, 28- 30th November, 2002, Thane, p. 21-27

14. Goswami SC, and G Padmavati, 1996. Zooplankton production, composition and diversity in the coastal waters of Goa. Indian Journal of Marine Sciences, 25: 91-97.

15. Haq SM and H Hassan, 1975. Larvae of shrimps of the genera Penaeus, Parapenaeopsis, and Metapenaeusfrom the coast of Pakistan. Pakistan Journal of Zoology, 7: 145-159.

16. Heinbokel JF, 1978.Studies on the functional role of tintinnids in the Southern California Bight: 1. Grazing and growth rates in laboratory cultures. Marine Biology, 47: 177-189.

17. Houde $E$ and JD Lovdal, 1982. Variability in Ichthyoplankton and microzooplankton abundances and feeding of fish larvae in Biscayne Bay, Florida.Estuarine, Coastal and Shelf Science, 18: 403-419.

18. Islam AKMN and A Aziz, 1975.A preliminary study on the zooplankton of the North-eastern Bay of Bengal. Bangladesh Journal of Zoology, 3: 125-138.

19. Jacob RM, NK Ramachandram and KR Vasantha, 1981. Zooplankton in relation to hydrography andpelagic fisheries in the inshore waters of Virhinjam, Trivandrum. Journal of the Marine Biological Association of India, 23: 62-76.

20. Kasturirangan LR, 1963. A key for the identification of the more common planktonic Copepoda of Indian coastal waters. Indian National Committee on Oceanic Research, Publication No. 2: 1-87. New Delhi.

21. Krisshnapillai S and GJ Subramonia Bhat, 1981. Note on the abundance of zooplankton and trawler catchduring the post monsoon months along the northwest coast of India. Journal of the Marine Biological Association of India, 23: 208-21.

22. Koga F, 1984 .Morphology, ecology, classification and specialization of copepods nauplius. Bulletin of Nansei Regional Fisheries Research Laboratory, 16: 95-229. 
23. Laval-Peuto M, JF Heinbokel, OR Anderson, F Rassoulzadegan and BFSherr, 1986. Role of microand nanozooplankton in marine food webs. Insect Science and its Application, 7: 387-395.

24. Muthu MS, NN Pillai and KV George, 1978.Larval development - Pattern of penaeid larval development and generic characters of the larvae of the genera Penaeus, Metapenaeusand Parapenaeopsis. Central Marine Fisheries Research Institute, Cochin, 28: 75-86.

25. Newell GE and RC Newell, 1979. Marine Plankton, a practical guide.Hutchinson of London. 244p.

26. Olivar MP and JM Fortuno, 1991. Guide to Ichthyoplankton of southeast Atlantic (Benguela Current region). Scientia Marina, 55: 1-383.

27. Omori $\mathrm{M}$ and $\mathrm{T}$ Ikeda, 1976. Methods in marine zooplankton ecology. A wiley-Interscience Publication, 332p.

28. Omori M and T Ikeda, 1984.Methods in Marine Zooplankton Ecology. John Wiley \& Sons, New York, $332 \mathrm{pp}$.

29. Patel MI, 1975, Pelagic copepods from the inshore waters off Saurashtra coast. Journal of the Marine Biological Association of India, 17: 658-663.

30. Paulinose VT, 1982. Key to the identification of larvae and post larvae of the penaeid prawns (Decapoda: Penaeidae) of the Indian Ocean. Mahasagar-bulletin of the National Institute of Oceanography, 15: 223-229.

31. Peter KJ, 1969. Preliminary report on the density of fish eggs and larvae in the Indian Ocean. Bulletin of National Institute of Sciences of India, 38: 854-863.

32. Pierce RW and JT Turner, 1994. Plankton studies in Buzzards Bay, Massachusetts, USA: IV. Tintinnids, 1987 to 1988. Marine Ecology Progress Series, 112: 235-240.

33. Rothlisberg PC, CJ Jackson and RC Pendrey, 1983. Specific identification and assessment of distribution and abundance of early penaeid shrimp larvae. The Biological Bulletin (Woods Hole) 164: 279-298.

34. Rothlisberg PC, CJ Jackson and RC Pendrey, 1987.Larval ecology of penaeids in the Gulf of Carpentaria, Australia.I. Assessing the reproductive activity of five species of Penaeusfrom the distribution and abundance of the zoeal stages. Australian Journal of Marine and Freshwater Research, 38: 1-17.

35. Sameoto DD, 1972. Distribution of Herring (Clupleaharengus) larvae along the southern coast of NovaScotia with observations on their growth and condition factor.Journal of the Fisheries Research Board of Canada, 29: 507-515.

36. Statistical Analysis System (SAS) 2003. User's Guide SAS/STA-t version.8th Edition. SAS, Institute, Inc. Cary, N. C., US.

37. Smirnov NN, 1996. Guides to the identification of the micro invertebrates of the continental waters of the world. cladocera: the chydorinae and sayciinae (chydoridae) of the world. SPB Academic Publishing. The Netherlands.11, 197p.

38. Srinivasan M, 1988.Species associations in Chaetognatha from the Arabian Sea.Journal of the Marine Biological Association of India, 30: 206-209.

39. Suwanrumpa W, 1983. Zooplankton in the western Gulf of Thailand. III. Relation between the distributionof zooplankton predators and fish larvae collected during January to October, 1981.Tech.Paper No.25/13. Marine Fisheries Division, Dept. of Fisheries, 18 p.

40. Tirmizi NM, N Aziz and WM Qureshi, 1987. Distribution of planktonic shrimp SergestessemissisBurkenroad, 1940 (Decapoda, Sergestidae) in the Indian Ocean with notes on juveniles. Crustaceana, 53: 15-28.

41. Wickstead JH, 1965. An introduction to the study of tropical plankton. Hutchinson and Co. Ltd. London. 155pp.

42. Wimpenny RS, 1966. The plankton of the sea. Faber and Faber LTD, London, 426p.

43. Zafar M, and N Mahmood, 1989. Studies on the distribution of zooplankton communities in the Satkhira estuarine system, Chittagong University Studies Science, 13: 115- 122.

44. Zafar M, 2000. Study on Sergestid shrimp Acetes in the vicinity of Matamuhuri river confluence, Bangladesh", Ph. D. Thesis, University of Chittagong, Bangladesh, 320p. 